\title{
Promoting Emergent Literacy Development on Early Childhood: a Case Study in Indonesian Families
}

\author{
Tri Puji Astuti, Anita Listiara, Jati Ariati \\ Diponegoro University, Faculty of Psychology, Jl. Prof. Soedarto, S.H., Semarang, Indonesia \\ Corresponding e-mail: a.listiara@undip.ac.id
}

\begin{abstract}
The purpose of this study was to describe the experience of Indonesian's families which living in suburban area in promoting the emergent literacy skills for their children. The participants of this study consisted of 51 mothers and 51 students of kindergarten, which were their children. This research was conducted by a case study approached. Data were collected through mothers' questionnaire, initial literacy skills assessment for the children, and interview with the mothers. The findings showed that families, especially mothers performed activities of local nurturing practices that promote acquiring in emergent literacy skills to their children. In addition, result indicated a necessity to obtain emergent literacy education for the mothers.
\end{abstract}

Keywords: case study, early childhood, emergent literacy skills, family environment, mothers' involvement

\section{INTRODUCTION}

McDevitt and Ormrod (2013) wrote that the introduction of initial stimulus in reading and writing activities enables early childhood to learn written language. For example, they will learn that each printed media provides different information with various purposes, such as item inventory lists, greeting cards, story books or newspapers. They will also recognize certain regulations for spoken language pronunciation and writing regiment from left to right or top to bottom. Basic knowledge such as the aforementioned activities that will give a foundation in developing reading and writing skills, which known as emergent literacy (McDevitt \& Ormrod, 2013).

Soderman, Gregory, \& McCarty (2005) stated literacy development as a process of skills development consisting of reading, writing, and verbal communication. They should also develop an ability to visualize their knowledge. Tomkins (as cited in Soderman, et al, 2005) described literacy as a tool for children to learn their environment and as a means to fully participate in a community.

The literacy learning process could be considered as a social process (Morrison, 2002).
Adults, peer groups, and other family members will affect a child's attempt in studying language and the context surrounding. Powell (as cited in Newland, Gapp, Jacobs, Reisetter, Syed, \& Wu, 2011) emphasized that parents are the first and foremost important teacher for a child. He also believed that the mother's belief is one of the prominent factor to her involvement in activities that empowers children's literacy skills development (Newland, et al, 2011). A family that consisted of parents and a child are subjects which played an important role in conducting nurture, education, and early childhood development program. Family is a major part of those programs, hence their involvement is necessary (Suryana, 2006).

Previous studies suggested an important influence from the home and family environment of various cultural background to the child's literacy development (Chansa-Kabali \& Westerholm, 2014; Chiu \& Ko, 2008; Newland, et al, 2011; Ng \& Yeo, 2013, Spedding, Harkins, Makin, \& Whiteman, 2007; Weigel, Martin, \& Bennett, 2006). Children who enjoyed their initial reading experience will likely become an enthusiastic reader in the future (Baker, et al; Vandermaas-Peeler, et al; as cited in McDevitt \& Ormrod, 2013). Interactive process will 
likely to occur in a home-environment that introduces literacy in early childhood, although the description of process would be different to each families (Chansa-Kabali \& Westerholm, 2014). This research is aimed to describe the experience of Indonesian families in promoting initial literacy skills of their children. This study will further explore the practices or efforts performed by the family to support early childhood in learning to write and read. Therefore, this study was conducted through a qualitative case study approach.

\section{CASE STUDY}

Case study approach emphasizes on a deep exploration of a bounded system according to an extensive data collection (Creswell, 2012). Bounded system means that the case was bounded for research purposes by time, place, or some physical boundaries. This study concentrated upon the developing patterns of behavior as a result of a group interaction during a certain time period. Therefore, this study prioritized to find a detailed description of the case rather than attempting to elaborate occurring themes along the way. This research highlights instrumental case study because it is more suitable to explore an issue.

\section{EMERGENT LITERACY SKILLS}

The literacy development process was beginning long before children started going to school. Since a child was born, he will gradually advance this ability until he could read and write (Brown, et al, as cited in Shoghi, Willersdorf, Braganza, \& McDonald, 2013). Children learn to talk and listen as a basic of literacy. Researches of initial literacy issues suggested that the roots of reading and writing was established by their experience in verbal language at the early childhood (Weigel, et al, 2006). When a child converses, reads, and observes items with letters like posters, logos, books, magazines, and newspapers all over the place, especially at home, they will immediately pay attention to the written language around them. By seeing those various written language, a child will learn its function. They will understand that written language is connected to the verbal language and both are forms of communication. Gunn, Simmons, and Kameemui (2005) has conducted literature study of 24 emergent literacy research and found that the experience of written language (by reading and writing) will help preschool children to develop an understanding of the rules, purposes, and functions of written language.

Hughes (2004) stated that children who failed to comprehend the functions of a writing and the benefits of reading will tend to have difficulties to become a successful reader. He studied the village children at Vanuatu, which has less chances to utilize written language or to experience activities related to literacy. Those children displayed a risk to fail in their literacy aspect due to lack of access to items related to writings. The emergent literacy skills will grow if they had a chance to interact with items related to writing activities, such as papers, pencils, parents who appreciate the literacy process as well as a model for writing and reading activities. Such condition was not established in the village areas of Vanuatu. It was also not found at the child of families from Aborigin and Torres Strait Islander, as Breen et al studied (as cited in Spedding, et al, 2007).

Family nurture that accommodates literacy development will determine the child's literacy skills when they participated in a formal school education, such as familiarizing them to read a book loudly. Unfortunately most families in various countries do not realize those rearing practices (HillClark, 2005). Families with a facilitative mother tend to develop the home literacy environment, such as by providing story books, storytelling, and shared-book reading. Children in such environment appeared more advance on the knowledge of writing as well as displaying a high interest to reading activities (Weigel, et al, 2006). Parents and teachers will face a significant challenge if there's a difference of cultural background between the family, neighbourhood and the school environment in developing literacy at early childhood (Caldwell, 2006).

\section{METHOD}

The participants of this research were 51 mothers and 51 students which were their children. The student participants came from two different kindergartens located in the suburban areas of Semarang Regency. All of the mothers only have one child in that particular class. The students were 4 to 5 years old. The mothers were housewives which education background ranged from a highschool graduate up to a diploma (D3). Data were collected in a kindergarten, which consisted of a simple building equipped with standard playing facilities for a kindergarten. 
Data was obtained by requesting the mother participants to complete a questionnaire and assessing the child participants' initial literacy. This study was using a Literate Home-Environment Questionnaire according to proposed theory by Weigel, et al (2006). This questionnaire consisted of sections aimed to reveal the activities related to nonwritten media, activities related to reading with or without the parents, activities related to independent or parents-assisted writing, and the child's current read-write ability.

While to assess initial literacy, this research used Initial Literacy Development Assessment designed according to the Get Ready to Read! (Whitehurst, 1999) test guidance. This assessment is applicable to two domains, vocal and written domains. It was conducted gradually and individually because there were fewer research assistants than the students assessed. Trained students of the Bachelor Program at the Psychology Faculty were appointed to carry the task of assisting. Interviews were also performed at several mother participants.

Data analysis was performed by describing a detailed description of a case and its setting, continued by an interpretation procedure (Creswell, 1998). While the answers of the questionnaire were organized and repeatedly read to formulize a holistic impression. The answers were then categorized. It is expected that this method could help emerging relevant meanings to the case (Creswell, 1998). The data are then rearranged according to the formed categories to establish patterns indicating the interdependency of the categories. Finally the researchers will be able to develop a naturalistic generalization or lesson learned, which is a generalization of findings that allows the community or other parties to learn from that particular case (Creswell, 1998). To ensure the quality standard of the data, we performed triangulation by conducting continuous confirmation between the members of researcher group, supporting theories, and data originated from the various data collection techniques applied.

\section{RESULTS}

This research found several unique patterns according to the experience of both the mother participants and her family during their times with their children which were in early childhood. The main patterns are the form of mother-child interaction, utilized media, and consequences. The description of each patterns are as follows: patterns of mother-child interaction, patterns of learning media, and patterns of consequences to the children.

\subsection{Patterns of mother-child interaction}

Mother participants explained that their child loves to watch television or child movies daily. The mother usually accompanies the child while watching television so that they could comment or explain the show. The mother can also re-tell the story of the watched movie. Besides, mothers or other adults in the family read a storybook to their child before going to bed, at least once a week. They enrich the story telling process by pointing pictures, giving labels, and pointing letters or words. This activity is usually carried in the bedroom or while lying on the floor because it is intentionnally to comfort the child to get asleep. The child usually participates in the story telling process by pointing pictures, flipping pages, calmly listens, naming human and object pictures, and also choosing a book to be read together.

Mothers allow their child to choose drawing than writing. While the child drawing, or coloring, the mother usually comments in telling them what to draw next as well as color suggestion. When the mother reads a story, the child is also asked to point the picture meant by the mother. The mother also demands other form of activity, such as pointing letters and words, or asking the child to flip the page.

Some of the mothers stated that they never read a story for their child. As for the mother who actually reads, they rarely offered question regarding the book, the storyline or even the characters of the story.

\subsection{Patterns of Learning Media}

Instead of going to the library, bookstore or practicing to press buttons on a communication device, mothers prefer to watch television and go to a familiar grocery shop periodically with their child. The mother usually allows the child to pick a snack to buy. The child then recognized the label on the pack because they saw it from television and the mother used to read it for them. Among items around the house, the child's attention are mostly related to the story books. They tend toward drawing and writing using pens, pencils, and crayons. 


\subsection{Patterns of Consequences to the children}

According to the mothers, the children's curiosity was expressed by opening books or pretending to read. For mothers, these expression are considered sufficient to tell that the children are happy. Some of them can write their name. While several findings were found from the result of children's initial literacy skill assessment; that on average they can answer correctly 12 problems out of 20 in 11 minutes. There are three problems that seemed too difficult for the children, because mostly they failed to answer it. Those three problems were related to book characteristic identification, letter and word identification within the context, identification of rhymes in syllables, and cultural influence.

Both children with high and low scores had difficulties to differ the front, rear, sides and inside part of a displayed book. One thirds of the children were able to notice the difference of the concept of writing and picture. But, they had difficulties to have a wordplay with rhymes.

Problems written in block letters tend to be recognized easier by children, hence they could answer correctly. While problems expressed with pictures of familiar items tend to be responded enthusiastically and loudly, albeit not always correct. For example, when the researchers displayed a picture of a goose, their answer were duck. It related with the environment which they lived that familiar with duck compared to goose. Half of the participants were able to perform the blending (combining two syllables to form a meaningful word according to one of the pictures displayed) and deletion (identifying pictures according to the task by removing a certain syllable) tasks.

According to the described patterns, the lesson learned are the existence of local nurturing practices and the need for emergent literacy education.

Local nurturing practices. Activities performed by the mothers (such as comforting, reading a story, giving opportunities to choose bookstories and meals, and directing a certain instruction in coloring) were the description of their experiences in nurturing their early childhood. We describe this as the local nurturing practices. Such activities were meant to comfort during the children bedtime. The mother's activities do not have any intention to develop emergent literacy skills. However, the local nurturing practices performed by the mother could help the child to learn the listening, reading, and coloring skills, all of which are part of the emergent literacy skills. It seems that the mother participants in this recent study has performed similar activities with the intended activities to promote child's emergent literacy skills in previous research.

Need for emergent literacy education. Mothers' behaviors that not intentionally to develop emergent literacy skills of their early childhood reflect the lack of knowledge of the parents and family to facilitate an emergent literacy skill development. The condition should become a consideration for the kindergarten institution as well as the surrounding communities, to provide contribution in the form of education regarding emergent literacy to the families with early childhood.

\section{DISCUSSION}

The mother participants in this study are graduated from high school up to diploma. Some of the participants has started to get used with telling stories to their children, while the rest are not used to do it regularly. Reading a book is considered less favoured by the child because they prefer to watch television or a movie. During the reading time, some the participants admitted that they weren't used to invite the child to explore by providing simple questions related to the story. They didn't have a specific place to perform that activity, as they mostly did that in the bedroom or lying on the floor to comfort the child in a bedtime.

The aforementioned condition was different with the findings of Chiu \& Ko (2008), which research was conducted in Taiwan. Their study emphasized that the mother's education background is essential in developing the child's reading skills. Mothers who graduated from at least high school suggested a more positive attitude towards the reading with child activity. Such attitude was supported by better reading behavior and buying more books than the mothers with lower education.

In assisting the children while watching television, the mother participants preferred to retell the story of the movie to the child. The study conducted by Castro et al (as cited in Chansa-Kabali \& Westerholm, 2014) in Peru discovered an opposite phenomena, where the parents encourages their child to retell the story of the movie they watched in television. That activity could affect the child's ability in verbal language. While in Zambia, parents of family with lower social-economy status invites their child to pretend as a teacher while the 
parents or siblings plays the student (Chansa-Kabali \& Westerholm, 2014).

One of the unique findings in this research was that the numerous amount of bookstore, library and basically places that provide books, were not considered as a destination to spend the participants' leisure time. Children were introduced to the benefits of print-awareness during their parent's shopping time. Practical dan usual tools for literacy media in the child's daily life such as invitation letters, promotional flyers, signs on the streets, logos, and symbols around the house weren't extensively used to introduce the child to the function of written language. Children participants were having difficulties in decoding and phonological awareness skills. They were interested in drawing rather than other literacy related behavior.

The phenomena described in this research suggested that some of the mother participants were attempting to read a story to their child at least once a week, while other participants weren't used to do so. The other unique experience was when the mother reads a story with a child in the bedroom, or at a chair or even on the floor, the activity was meant to help the child to sleep. This condition was different with the circumstance described in the study conducted by $\mathrm{Ng} \&$ Yeo (2013) at the Chinese and Malay community in Malaysia. They emphasized the importance of interaction quality between the parents or adults with the child, integration or combination of the daily language with an environment saturated with books, and utilization of clear instruction purposed to improve the child's literacy skills. Therefore parents should encourage dialogue, read a book or even sing together in order to support their earlyhood children in practicing or learning through entertaining means.

\section{LIMITATION OF THE RESEARCH}

We suggested that the result of this study could gain more depth and detail if supported by a focus group interview for the mother participants, more than one time. Aside from that, it is important to describe their daily experience in their residence. This research also has neither elaborate the experience nor the treatment from the teachers related to the development of emergent literacy of the students as well as the availability of reading materials for the students. The researcher also believed that the initial literacy assessment applied in this research still need to consider the cultural background of the participants, and to have the psychometric quality reviewed.

\section{CONCLUSION}

This research described some unique experience of families from different cultural background with the previous studies. The findings emphasized the importance of family, particularly the parents or other adults to facilitate the child in undergoing a fun learning to support his emergent literacy skill development as early as possible.

\section{ACKNOWLEDGMENTS}

Thanks to all the participants who took part in this research and the people who took us in contact with them. Also thanks to all the research assistants for conducting the assessment sessions. We would like to acknowledge Tri Puji Astuti's family in supporting us to write this article.

\section{REFERENCES}

Auerbach, C.F., \& Silverstein, L.B. (2003). Qualitative data: An introduction to coding and analysis. New York: New York University Press.

Caldwell, T.R. (2006). Primary literacy achievement: A collaborative urban partnership. Early Childhood Research \& Practice. Retrieved from http://www.thefreelibrary.com/Primary+literac $\mathrm{y}+\mathrm{achievement} \% 3 \mathrm{a}+\mathrm{a}+$ collaborative+urban+pa rtnership.-a0153900244

Chansa-Kabali, T., \& Westerholm, J. (2014). The role of family on pathways to acquiring early reading skills in Lusaka's low-income communities. Human Technology: An Interdisciplinary Journal on Humans in ICT Environments, 10 (1), 5 - 21.

Chiu, C.H., \& Ko, H.W. (2008). Parental factors related to children's reading: Evidence from comparing transnational marriage families and local families. Paper. Retrieved from http://www.iea.nl/fileadmin/user_upload/IRC/I RC_2008/Papers/IRC2008_Chiu_Ko.pdf

Creswell, J.W. (1998). Qualitative inquiry and research design: Choosing among five traditions. Thousand Oaks: Sage.

Creswell, J.W. (2012). Educational research: Planning, conducting, and evaluating 
quantitative and qualitative research. New Jersey: Pearson Education, Inc.

Gunn, B.K., Simmons, D.C., \& Kameemui, E.J. (2005). Emergent Literacy: Synthesis of the research. National Center to Improve The Tools of Educators, U.S. Office of Special Education Programs.

Hill-Clark, K.Y. (2005). Families as educators: Supporting literacy development. Retrieved from http://www.thefreelibrary.com/Families+as+ed ucators\%3a+supporting+literacy+development. $-\mathrm{a} 0138142256$

Hughes, D. (2004). Reflecting on early literacy development in the context of Vanuatu. Contemporary Issues in Early Childhood, 5 (3).

McDevitt, T.M., \& Ormrod, J.E. (2013). Child development and education. 5th edition. Boston: Pearson.

Morrison, G.S. (2002). Contemporary curricullum $K-8$. Boston: Allyn \& Bacon.

Newland, L.A., Gapp, S.C., Jacobs, G.M., Reisetter, M.F., Syed, D.C., \& Wu, C.H. (2011). Mother's beliefs and involvement: Links with preschool literacy development. International Journal of Psychology: A Biopsychosocial Approach, 69 (9), 67 - 90.

Ng, P.F., \& Yeo, K.J. (2013). Emergent literacy in a print-rich multilingual home environment. International Journal of Humanities and Social Science, 3 (13), 146 - 155.

Shoghi, A., Willersdorf, E., Braganza, L., \& McDonald, M. (2013). 2013 Let”s read literature review. Victoria: The Royal Children's Hospital Centre for Community Child Health, Murdoch Childrens Research Institute.

Soderman, A.K., Gregory, K.M., \& McCarty, L.T. (2005). Scaffolding emergent literacy: A childcentered approach for preschool through grade 5. Boston: Pearson Education, Inc.

Spedding, S., Harkins, J., Makin, L., \& Whiteman, P. (2007). Investigating children's early literacy learning in family and community contexts: Review of the related literature. Government of South Australia, Department of Education and Children's Services.

Suryana, S. (2006). Pendidikan dan pengembangan bagi anak usia dini. Paper. Presented in National Seminar: Empowering The Community in Conducting Early Childhood Educational Program at Semarang.

Weigel, D.J., Martin, S.S., \& Bennett, K.K. (2006). Mothers' literacy beliefs: Connections with the home literacy environment and pre-school children's literacy development. Journal of Early Childhood Literacy, 6 (2), 191 - 211
Whitehurst, G.J. (1999). Measurement of emerging literacy and literacy outcomes. Retrieved from http://www.acf.hhs.gov/programs/hsb/research/ hsreac/jun1999/whitehurst.htm 